\title{
Yield response of vegetables to tillage techniques on a Vertisol of the semiarid region of Puerto Rico'
}

\author{
Héctor M. Lugo-Mercado, ${ }^{2}$ José Badillo-F'eliciano, ${ }^{2}$ Esaú Orengo, ${ }^{3}$ \\ Carlos Ortiz, ${ }^{3}$ and Frederich $H$. Beinroth
}

\begin{abstract}
Three experiments were conducted on a Vertisol of the southwest region of Puerto Rico to evaluate the effects of no-till vs. three different tillage techniques on the yield of corn, pepper, watermelon, eggplant, bean and fomato. Soil treatments consisted of no till (undisturbed), minimum till (chisel plowing), deep till (disk plowing to $45-\mathrm{cm}$ ) and conventional till (15-cm depth). Each treated plot was split info two or three subplots where test crops were planted. A positive response to conventional till was observed for pepper, watermelon, bean and tomato. No statistically significant differences were observed when the yields of all crops grown on minimum-till plots were compared with the no-till treatment. This suggests the possibility that corn and eggplant can be planted in no-till soils similar to Santa Isabel clay without reducing yield at least for 1 year. Bean, tomato, watermelon and pepper, however, might require some type of tillage. Nevertheless, the results in general substantiate the view that production costs can be lowered by decreasing tilloge input without reducing yield.
\end{abstract}

\section{INTRODUCTION}

Because Puerto Rico has one of the highest population densities of the world and less land in cultivation, it depends on imports for most of its food. Therefore, it is imperative to improve soil management practices in order to maximize productivity and preserve farm land. Tillage practices are among the main factors that not only affect productivity but also enhance soil conservation.

Conservation tillage is a method defined by the Soil Conservation Society of America as "any tillage system that reduces loss of soil or water relative to conventional tillage; often a form of noninversion tillage that retains protective amounts of residue mulch on surface" $(13,17)$. This method is increasingly applied, especially in the United States (19).

'Manuseript submitted to Editorial Board 4 June 1987.

${ }^{2}$ Agronomist, Agronomy and Soils Department, Agricultural Experiment Station, Mayagüez Campus, University of Puerto Rico.

'Research Assistant, Agricultural Experiment Station, University of Puerto Rico, Mayagüez Campus, Lajas, P, R.

${ }^{4}$ Professor, Agronomy and Soils Department, Mayagüez Campus, Univ. P. R. 
For example, McGregor et al. observed that the annual amount of erosion was reduced from $17.5 \mathrm{t} / \mathrm{ha}$ to 1.8 t/ha when no tillage was used on a highly erodible soil of Mississippi (14). In most cases, these conservation practices have resulted in higher yields in the long run. However, studies over the past 30 years in Senegal, a tropical African nation, indicated that plowing increases crop yield on deep sandy and sandy clay soils by improving soil physical conditions and biological activity while promoting root-system development. Yet, other forms of minimum-tillage have produced good results in different ecological zones of West Africa (5).

It is evident, therefore, that there is no single, specific tillage technique that works equally well under all agroecological conditions. The type of land preparation techniques giving optimal results will depend on the interaction of such factors as soil physical properties, crop species and climate. Specific trials for combinations of soil, crop, and other site factors must be conducted in order to develop appropriate tillage strategies.

In Puerto Rico, Abruña et al. (1) and Lugo et al. $(10,11,12)$ demmonstrated that the need for tillage practices varies with crops, soils and location. Lugo et al. $(10,11,12)$ obtained a significantly different response to a specific tillage practice for pepper (plots plowed four times at $45-\mathrm{cm}$ depth), and corn and beans, grown simultaneously on the same plots of a San Antón soil (Cumulic Haplustoll). Conversely, Abruña et al., working on an Ultisol in the mountain region of Puerto Rico, reported that tanier planted without tillage yielded as well as with conventional tillage. But Lugo et al. (10) observed a 75\% reduction in yield of the same species grown on undisturbed plots (no till) of Coto soil, an Oxisol in northwestern Puerto Rico. Other researchers had recorded similar interactions between soil, crop species, and location with respect to tillage response $(3,4,5,7,8,9,15,16,18,19)$.

This study was conducted to compare the effects of several tillage techniques versus no till on the yield of corn, watermelon, pepper, bean, eggplant and tomato. Each crop species was grown on a Vertisol of the semiarid southwest region of Puerto Rico.

\section{MATERIAL AND METHODS}

Tillage strategies were evaluated in a series of experiments established at the Lajas Research Center from 1983 to 1986. The trials were conducted on a Vertisol, series Santa Isabel clay. This soil is a Udic Pellustert of the fine, montmorillinitic, isohyperthermic family. It is located in a semiarid region (750 to $1000-\mathrm{mm}$ rainfall annually), has a CEC of $52 \mathrm{cmol} / \mathrm{kg}$ of soil, and a $\mathrm{pH}$ ranging from 6.8 to 7.8. The land used for the experiments had lain fallow for at least 2 years before the initial experiment in 1983. 
The experimental design for all trials was a split-plot arrangement of a randomized complete block, replicated four times, with land preparation methods assigned to main plots and the test crop species to subplots. Once treated, each main plot $(14 \times 6 \mathrm{~m})$ was subdivided into 3 subplots $(6 \times 4 \mathrm{~m})$. The same treated and nontreated plots were used for all three experiments; that is, the no till, minimum till and conventional till plots used for the first experiment (1983-84) were the same for all subsequent experiments. Fertilization and irrigation, as well as pest and disease control, followed the Agricultural Experiment Station recommendations (6).

Yields were measured and recorded. Chemical and physical soil analyses such as $\mathrm{pH}$, cation exchange capacity (CEC), organic matter and nutrients, $\mathrm{N}, \mathrm{P}, \mathrm{K}, \mathrm{Ca}$ and $\mathrm{Mg}$ were determined according to Black (2). A recording instrument with a core area of $4 \mathrm{~mm}^{2}$ was employed for penetrometer resistance measurements for each plot at harvest throughout the study.

The experimental treatments for the first experiment (1983-84) were as follows: 1) No-till; 2) conventional-till (plowed twice at 15-cm depth and 2-week intervals); 3) deep-till (plowed at 45-cm depth); and 4) minimum-till (chiseling at $30-\mathrm{cm}$ depth). Com, pepper, and watermelon were used as test crops.

For the second and third trials, the deep till treatment was omitted; that is, no till was compared only with minimum and conventional till. Bean, eggplant, and tomato were assigned to the subplots.

In the third experiment (fall of 1985 to the spring of 1986), plots tilled in the second experiment were split in two subplots, one of which was left undisturbed and the other plowed, as in the 1984-85 experiment. Tomato and bean were then planted in half of each sub-plot. The objective was to measure residual effects of the land preparation technique.

\section{RESULTS AND DISCUSSION}

Tables 1, 2 and 3 present the results of the three experiments. Table 1 summarizes the results of 1983-84. The statistical analyses reveal no significant differences among tillage practices when corn and watermelon were used as test crops. However, it is evident that watermelon yields increased with tillage input; for example, the plants grown on deep-tillage plots out yielded the no-till ones by a four to one margin. The absence of statistically significant variation was probably due to the typically great variability of flowering, pollination, and fruit decay before harvesting of this crop, which produced large differences among replicates. On the other hand, peppers planted on conventionally- and deepplowed land yielded from two to three times more than the no till or minimum till treatments. With pepper, the deep till treatment produced the only statistically significant difference among the tillage methods 
TABLE 1.-Corn, pepper and watermelon yields of the 1983-84 experiment as affectd by tillage techniques

\begin{tabular}{lrrr}
\hline \multirow{2}{*}{ Tillage technique } & \multicolumn{1}{c}{ Yield $(\mathrm{kg} / \mathrm{ha})$} & \\
\cline { 2 - 4 } & \multicolumn{1}{c}{ Corn } & Pepper & Watermelon \\
\hline No till & $11,533 \mathrm{a}$ & $6,625 \mathrm{a}$ & $9,906 \mathrm{a}$ \\
Minimum till & $9,735 \mathrm{a}$ & $6,268 \mathrm{a}$ & $21,707 \mathrm{a}$ \\
Conventional till & $9,881 \mathrm{a}$ & $11,089 \mathrm{a}$ & $37,270 \mathrm{a}$ \\
Deep till & $9,985 \mathrm{a}$ & $19,006 \mathrm{~b}$ & $38,583 \mathrm{a}$ \\
\hline
\end{tabular}

'Means (of 4 replicates) followed by the same letter do not differ statistically.

tested. The results agree with those obtained by Lugo et al. (11) on a San Antón soil in Puerto Rico's southern region.

Table 2 presents the results of the 1984-85 trials. Significant increases in yields of marketable tomato and bean were obtained with conventional till as compared with no-till. It appears that the observed yield increases were the result of tillage effects on plant population, since the average number of plants on tilled plots was about $50 \%$ higher than with no-till; thus a statistically significant difference for plant population was found between the tillage and no-tillage treatments.

The tillage effect on bean and tomato yields was the opposite of that found by Lugo et al. at Fortuna in a Mollisol (San Antón series). They obtained no statistically significant differences among various tillage practices and no tillage $(11,12)$. Eggplant indicated the same trend, that is, yield increased with tillage, but without attaining statistically significant differences.

Contrary to the 1983 trial, a comparison of the tillage treatments by statistical analysis of combined yields demonstrates a significant response to tillage inputs. As expected, there was a highly-significant climate-soil-crop interaction.

Table 3 summarizes the results of the 1985-86 experiment. Conventional tillage, just prior to planting, increased yields of bean and tomato over those of the other treatments tested. However, bean yield increases from conventional till just prior to planting, was the only response of statistical significance. This not only confirms the $1984-85$ results, but

TABLE: 2-Bean, eggplant and tomato yields of the 19894-85 experiment as affected by tillage technigues

\begin{tabular}{|c|c|c|c|}
\hline \multirow{2}{*}{ Tillage techniques } & \multicolumn{3}{|c|}{ Yield kg $/ \mathrm{ha}$} \\
\hline & Bean & Eggplant & Tomato \\
\hline Notill & $182 a^{\prime}$ & 5281 a & $4108 \mathrm{a}$ \\
\hline Minimum till & $372 \mathrm{ab}$ & $8416 a$ & $5400 \mathrm{a}$ \\
\hline Conventional till & $585 \mathrm{~b}$ & $7950 \mathrm{a}$ & $10,777 \mathrm{~b}$ \\
\hline
\end{tabular}

' Means (of 4 replicates) followed by the same letter do not differ statistically. 
TABLE 3.-Residual effect of the 1984-85 tillage practices as compared to the same land preparation method performed just before planting the 1985-86 tomato and bean crops

\begin{tabular}{lcr}
\hline \multicolumn{1}{c}{ Treatment } & \multicolumn{2}{c}{ Yield (kg/ha) $^{1}$} \\
\cline { 3 - 3 } & Bean & Tomato \\
\hline No till & $735 \mathrm{a}^{2}$ & $22,024 \mathrm{a}$ \\
Minimum till (Previous year) & $756 \mathrm{a}$ & $17,977 \mathrm{a}$ \\
Minimum till (Before planting) & $585 \mathrm{a}$ & $19,408 \mathrm{a}$ \\
Conventional till (previous year) & $652 \mathrm{a}$ & $27,972 \mathrm{a}$ \\
Conventional till & $1,235 \mathrm{~b}$ & $29,306 \mathrm{a}$ \\
\hline
\end{tabular}

'Planted on the same plots used for the 1984-85 experiment.

${ }^{2}$ Mean of 4 replicates followed by the same letter do not differ statistically.

also indicates that the beneficial tillage effect on this particular soil (Santa Isabel clay) declines after 1 year.

With regard to tomato, it appears that this crop is not as sensitive as beans to the declining tillage effect. The differences between the yield on the conventional-till just before planting and the conventional-till a year earlier were quite small (table 3).

As tables 4 and 5 indicate, the soil used for the study reported herein was in excellent physical and chemical condition. This explains in part the absence of significant differences between minimum till, and in most cases no-till, as compared with conventional till. That is, the typically higher mechanical impedance found in no-till soil was less detrimental because of naturally favorable physical properties and higher concentration of available nutrients.

It is therefore evident, that for most vegetable crops grown with minimum- or even no-till techniques in soils similar to Santa Isabel clay, good yields can be expected. Additional studies are needed, however, to cope with weeds, control of insects and diseases, and with more efficient use of fertilizer. The present results corroborate conclusions from a similar study on a Mollisol soil (San Antón series) of the same region of the island $(11,12)$.

TABLE 4.-Selected chemical analysis of the experimental plots

\begin{tabular}{|c|c|c|c|c|c|c|}
\hline \multirow{2}{*}{ Treatments } & \multirow[b]{2}{*}{$p \mathrm{H}$} & \multicolumn{5}{|c|}{ Chemical analysis' } \\
\hline & & $P$ & $\mathrm{~K}$ & $\mathrm{Ca}$ & $\mathrm{Mg}$ & $\mathrm{Na}$ \\
\hline No till & 6.13 & 43 & 270 & 3884 & 1892 & 129 \\
\hline Minimum till & 6.02 & 93 & 315 & 3875 & 1805 & 127 \\
\hline Conventional till & 6.08 & 38 & 211 & 3913 & 1907 & 133 \\
\hline
\end{tabular}

${ }^{1}$ Average of four replicates. 
TABLE 5.- Resistance to penetration, \% aggregales and bulk density of the experimental plots

\begin{tabular}{|c|c|c|c|c|c|}
\hline \multirow{2}{*}{ Treatment } & \multicolumn{3}{|c|}{$\begin{array}{l}\text { Resistance to penetration } \\
\text { depth (cm) }\end{array}$} & \multirow{2}{*}{ Aggregates } & \multirow{2}{*}{ Bulk density } \\
\hline & 7.5 & 16.0 & 23.0 & & \\
\hline & \multicolumn{3}{|c|}{$\mathrm{kg} / \mathrm{cm}$} & $\%$ & $m g / m m^{x}$ \\
\hline No till & 16.4 & 27.7 & 30.0 & $70.8^{1}$ & 1.33 \\
\hline Minimum till & 15.7 & 36.0 & 29.3 & 63.0 & $1.2 \mathrm{I}^{1}$ \\
\hline Conventional till & 10.6 & 25.5 & 30.8 & 61.4 & 1.30 \\
\hline
\end{tabular}

'Significant difference $(5 \%)$ over the other two land preparation methods.

\section{RESUMEN}

Rendimientos de algunas hortalizas en varios tipos de labranza en un Vertisol de la región semiárida de Puerto Rico

En tres experimentos en un suela Vertisol de la región suroeste de Puerto Rico para evaluar el efecto de tres tipos de labranza con cosecha sin labranza en cuanto al rendimiento de maíz, pimiento, melón, berenjena, habichuela $y$ tomate. Los tratamientos fueron sin labranza, labranza mínima, labranza convencional y labranza profunda. Todas las parcelas se prepararon de la manera correspondiente, se dividieron en 2 ó 3 subparcelas en las cuales se sembraron los cultivos de prueba.

Hubo una respuesta positiva a la labranza convencional cuando se comparó con la sin labranza en pimiento, melón, habichuela y tomate, pero hubo diferencias estadísticamente significativas al comparar los rendimientos con labranza mínima y los de la sin labranza.

Estas observaciones sugieren la posibilidad de que el maiz y la berenjena puedan sembrarse en suelos similares a los de Santa Isabel sin arar, sin que disminuya la producción. Pimiento, melón, habichuela y tomate pudieran requerir algún tipo de labranza. En general, los resultados tienden a establecer que se pueden reducir los cosfos de producción invirtiendo menos en la labranza sin que se reduzca la producción.

\section{LITERATURE CITED}

1. Abruña, F., E. G. Boneta, J. Vicente-Chandler and S. Silva, 1967. Experiments on tanier production with conservation in Puerto Rico's mountain region. $J$. Agric. Univ. P. R. 51: $167-75$.

2. Black, C. A., Ed, 1965. Methods of Soil Analysis. Part 1 and 2. Adv. in Agronomy 9: 552-1476. Am. Soc. Agron., Madison, Wisc.

3. Blevins, R., 1970. No tillage suitability to Kentucky soil. In: Phillips, R., G. Thomas and R. Blevins, Eds. No-tillage research: Research Reports and Reviews. University of Kentucky. Pp. 8.

4. Cannel, R. Q., 1983. No tillage in relation to soil conditions and climate. In: I. 0. Akobundu and A. E. Deutsch, Eds. No Tillage Crop Production in the Tropies. Published for the West African and International Weed Science Societies by the International Plant Protection Center, Oregon State Univ, Corvallis, OR.

5. Chopard, J. L., 1983. Effeets of Plowing and Minimum Soil Preparation in Senegal, Ivory Coast and Togo. In: I. O. Akobundu and A. E. Deutsch, Eds. No Tillage Crop Production in the Tropies. Published for the West African and International Weed 
Science Societies by the International Plant Protection Center, Oregon State Univ., Corvallis, $O R$.

6. Estación Experimental Agrícola, 1979. Conjunto Tecnológico para la Producción de Hortalizas. Publ. 102. Esta. Exp. Agric. Univ. P. R., Río Piedras, P. R.

7. Irizarry, H., E. Rivera, J. A. Rodriguez and J, J. Green, 1978. Effect of planting pattern and population density on yield and quality of horn-type Maricongo plantain (Musa acuminata $\times$ M. balbisiana, AAB) in north central Puerto Rico. J. Agric. Univ. P. R. 62: 214-23.

8. Lal, R., 1979. No tillage farming in the tropics. In: R. Phillips, C. Thomas and R. Blevins, Eds, No Tillage Research: Research Reports and Review. Univ. Kentucky, pp. 103-51.

9. -1983 . Soil conditions and tillage methods in the tropics. In: I. O. Akobundu and A. E. Deutsch, Eds. No Tillage Crop Production in the Tropics. Published for the West African and International Weed Science Societies by the International Plant Protection Center, Oregon State Univ., Corvallis, OR.

10. Lugo-Mercado, H. M., J. Badillo-Feliciano and J. López-García, 1978. Effects of soil compaction on tanier yields. J. Agric. Univ. P. R. 62; 52-6.

11. — - - and F. H. Ortiz-Alvarado, 1984. Comparison of no-tillage versus various tillage methods on maize, field beans and pepper's yield grown on a Mollisol of southern Puerto Rico. J. Agric. Univ. R. R. 68 (4): 349-54.

12. $\_,-$and,- 1986 . Yield lesponse of water melon, tomato and pigeon pea to land preparation techniques in southern Puerto Rico, J. Agric. Univ. P. R. 71 (2): 203-08.

13. Mannering, J. V. and C. R. Fenster, 1983. What is Conservation Tillage? J. Soil and Water Conservation 38 (3): 141-43.

14. McGregor, K. C., J. D. Greer and G. E. Gorley, 1975. Erosion control with no-till cropping practices. Trans. Am. Soc. Agric. Congress 18: 918-20.

15. Moschler, W., G. Shear, D. Martens, G. Jones and R. Willmowth, 1972. Comparative yield and fertilizer efficiency of no-tillage and conventionally tillage corn. Agron. J. 64 (2): 229-31.

16. Olaniyan, G. 0., 1983. No-tillage production of maize, rice and cowpea in Nigeria. In: I. 0. Akobunclu and A. E. Deutsch, Eds. No Tillage Crop Production in the Tropics. Published for the West African and International Weed Science Societies by the International Plant Protection Center, Oregon State Univ, Corvallis, OR.

17. Soil Conservation Society of America, 1982. Resource conservation glossary. Ankeny, Iowa.

18. Vicente-Chandler, J., R. Costas and E. Boneta, 1966. High crop yield produced with or without tillage on three typical soils of the humid region of Puerto Rico. J. Agric. Univ. P. R. 50 (2): 146-50.

19. Young, H. M., Jr., 1982. No-Tillage Farming. No-Till Farmer, Inc, Brookfield, Wis. 